\title{
Detection of Bartonella and Rickettsia in small mammals and their ectoparasites in México
}

\author{
Sokani Sánchez-Montes', Martín Yair Cabrera-Garrido², César A. Ríos-Muñoz ${ }^{1,3}$, Ali Zeltzin Lira-Olguin²; Roxana Acosta-Gutiérrez², Mario \\ Mata-Galindo ${ }^{1}$, Kevin Hernández-Vilchis ${ }^{1}$, D. Melissa Navarrete-Sotelo ${ }^{1}$, Pablo Colunga-Salas ${ }^{1,2}$, Livia LeÓn-Paniagua ${ }^{2}$ and Ingeborg BeCker ${ }^{1 *}$ \\ ${ }^{1}$ Centro de Medicina Tropical, Unidad de Medicina Experimental, Facultad de Medicina. Universidad Nacional Autónoma de \\ México. Dr. Balmis 148, CP. 06726, Ciudad de México. México. Email: sok10108@gmail.com (SSM), rmunoz98@gmail.com \\ (CARM), mata316@ciencias.unam.mx (MMG), chopa95@ciencias.unam.mx (KHV),dmel1231@gmail.com (MNS), colungasalas@ \\ gmail.com (PCS), becker@servidor.unam.mx (IB). \\ ${ }^{2}$ Museo de Zoología "Alfonso L. Herrera", Departamento de Biología Evolutiva, Facultad de Ciencias, Universidad Nacional \\ Autónoma de México. Avenida Universidad 3000, CP. 04510, Ciudad de México México. Email: bmw mark@comunidad.unam. \\ $\underline{m x}$ (MYCG), alizeltzin@ciencias.unam.mx (AZLO), roxana a2003@yahoo.com.mx (RAG), colungasalas@gmail.com (PCS), lp@ \\ ciencias.unam.mx (LLP). \\ ${ }^{3}$ Laboratorio de Arqueozoología, Subdirección de Laboratorios y Apoyo Académico, Instituto Nacional de Antropología e \\ Historia. Moneda 16, CP. 06060, Ciudad de México. México. Email: rmunoz98@gmail.com (CARM). \\ * Corresponding author.
}

Fleas and sucking lice are important vectors of multiple pathogens causing major epidemics worldwide. However these insects are vectors of a wide range of largely understudied and unattended pathogens, especially several species of bacteria's of the genera Bartonella and Rickettsia. For this reason the aim of the present work was to identify the presence and diversity of Bartonella and Rickettsia species in endemic murine typhus foci in Hidalgo, México. A cross-sectional study was carried out to collect small mammals and their associated ectoparasites during October, 2014. Samples of liver and ear of hosts, and ectoparasites were fixed in absolute ethanol and examined to identify the presence of Bartonella and Rickettsia DNA by the amplification of specific fragments of the gltA and ompB genes using conventional PCR. The recovered sequences were compared with those deposited in GenBank, and phylogenetic analyzes were carried out to identify the position of the pathogens detected with respect to the valid species previously reported worldwide. A total of 47 fleas and 172 sucking lice, belonging to five families (Ceratophyllidae, Leptopsyllidae, Ctenophtalmidae, Hoplopleuridae, Polyplacidae) and related to six species were collected from 40 rodents of four species and one shrew. Only four hosts (two P. beatae, and two R. norvergicus) were positive to Bartonella elizabethae, Bartonella vinsonii and Rickettsia typhi. In the case of ectoparasites, 23 specimens of two flea species (Peromyscopsylla hesperomys and Plusaetis mathesoni) tested positive for B. vinsonii. No evidence of Bartonella or Rickettsia was detected in any lice. Our findings represent the first record of Bartonella elizabethae a confirmed zoonotic pathogen causing endocarditis in México and several new associations of Bartonella with Mexican flea species, which highlight the importance of the establishment of active entomological surveillance in wildlife.

Las pulgas y los piojos son vectores de patógenos causantes de epidemias de importancia histórica. Sin embargo, estos insectos son vectores de una amplia gama de patógenos poco estudiados y no atendidos, especialmente varias especies de bacterias de los géneros Bartonella y Rickettsia. Por este motivo, el objetivo del presente trabajo fue identificar la presencia y diversidad de las especies de Bartonella y Rickettsia en un foco de tifus murino en el estado de Hidalgo, México. Se realizó un estudio transversal para recolectar hospederos y sus ectoparásitos durante octubre de 2014. Las muestras de hígado y oreja de los hospederos y los ectoparásitos se fijaron en etanol absoluto y se examinaron para identificar la presencia de ADN de Bartonella y Rickettsia mediante la extracción de DNA y amplificación de fragmentos específicos de los genes gltA y ompB. Las secuencias obtenidas fueron comparadas con aquellas depositadas en GenBank y se realizaron análisis filogenéticos para identificar la posición de los patógenos detectados respecto a las especies válidas previamente reportadas a nivel mundial. Se recolectaron un total de 47 pulgas y 172 piojos chupadores, pertenecientes a seis especies de cinco familias (Ceratophyllidae, Leptopsyllidae, Ctenophtalmidae, Hoplopleuridae, Polyplacidae) asociados con 40 roedores de cuatro especies y una musaraña. Sólo cuatro hospederos (dos $P$. beatae, y dos $R$. norvergicus) resultaron positivos para Bartonella elizabethae, Bartonella vinsonii y Rickettsia typhi. En el caso de los ectoparásitos, 23 ejemplares de dos especies de pulgas (Peromyscopsylla hesperomys y Plusaetis mathesoni) fueron positivos para B. vinsonii. No se detectó evidencia de ninguno de los dos patógenos en los piojos analizados. Nuestros hallazgos representan el primer registro de Bartonella elizabethae, un patógeno zoonótico confirmado que causa endocarditis en México y varias asociaciones nuevas de Bartonella con especies de pulgas mexicanas, lo cual resalta la necesidad de implementar vigilancia entomológica activa para el monitoreo de estos patógenos en animales silvestres.

Keywords: Bartonella elizabethae; emerging diseases; Rickettsia typhi; small mammals; vectors.

(C) 2019 Asociación Mexicana de Mastozoología, www.mastozoologiamexicana.org

\section{Introduction}

Fleas and sucking lice are important vectors of multiple pathogens causing major epidemics worldwide, such as plague (Yersinia pestis) and epidemic typhus (Rickettsia prowazekii). Despite the historical importance of both diseases, this group of ectoparasites has been little studied with respect to other vectors such as mosquitoes or ticks (Gillespie et al. 2009; Bitam et al. 2010; Eisen and Gage 2012). However, these groups of insects are hosts for a wide range of largely understudied pathogens, especially several species of bacteria of the genera Bartonella and Rickettsia (Bitam et al. 2010). The genus Bartonella includes 
at least 33 species of Gram-negative, intracellular and slowgrowing coccobacilli with complex life cycles including multiple vertebrate hosts and vectors, such as $B$. elizabethae and $B$. vinsonii arupensis, declared pathogens causing endocarditis in humans and dogs (Breitschwerdt and Kordick 2000; Tsai et al. 2011; Kosoy et al. 2012; Regier et al. 2016). On the other hand, Rickettsia encompasses 26 species of obligate intracellular bacteria which are transmitted by different groups of hematophagous arthropods such as ticks, lice and fleas (Fournier and Raoult 2009; Merhej et al. 2014). Rickettsia species are classified into four groups, two of which are pathogens for man: members of the Spotted Fever group [SGF] (R. conorii, R. massiliae, $R$. rickettsii and $R$. parkeri) and Typhus group [TG] (R. prowazekii and R. typhi), this latter group is transmitted exclusively by lice and fleas, which cause epidemic and murine typhus (Fournier et al. 2003; Fournier and Raoult 2009).

In recent decades with the advent of molecular biology techniques, the number of species or strains of both bacteria genera has increased exponentially (Merhej et al. 2014; Regier et al. 2016). Particularly, fleas and sucking lice associated with rodents are the groups in which more studies have focused for the detection of pathogens, with the identification of 16 validated species of Bartonella, nine of Rickettsia and more than 17 new linages near to several validated taxa (but which require isolation for formal identification) for both genera, associated with 45 flea species and seven sucking lice which are also associated with 42 species of rodents in 24 countries around the world (Table 1).

Table 1. Bartonella and Rickettsia species detected in fleas and sucking lice associated with rodents worldwide

\begin{tabular}{|c|c|c|c|c|}
\hline Bacteria species & Flea & Host & Country & References \\
\hline \multirow[t]{2}{*}{ B. birtlesii } & Ctenophtalmus andorrensis catalanensis & Apodemus sylvaticus & Spain & Cevidanes et al. 2017 \\
\hline & Leptopsylla taschenbergi amitina & A. sylvaticus & Spain & Cevidanes et al. 2017 \\
\hline B. coopersplainsensis & Stephanocircus pectinipes & Rattus fuscipes & Australia & Kaewmongkol et al. 2011 \\
\hline B. doshiae & Xenopsylla cheopis & Rattus sp. & Afghanistan & Marie et al. 2006 \\
\hline \multirow[t]{9}{*}{ B. elizabethae } & Leptopsylla segnis & Mus spretus & Algeria & Bitam et al. 2012 \\
\hline & Synosternus cleopatrae & Gerbillus pyramidum & Israel & Morick et al. 2010 \\
\hline & Synopsyllus fonquerniei & Rattus rattus & Madagascar & Brook et al. 2017 \\
\hline & X. cheopis & Rattus norvergicus & Algeria & Bitam et al. 2012 \\
\hline & & & USA & Frye et al. 2015 \\
\hline & & R. rattus & Algeria & Bitam et al. 2012 \\
\hline & & Rattus tanezumi & Indonesia & Winoto et al. 2005 \\
\hline & & Rattus sp. & Afghanistan & Marie et al. 2006 \\
\hline & & & Nigeria & Kamani et al. 2013 \\
\hline \multirow[t]{7}{*}{ B. grahamii } & Ctenophthalmus agyrtes & ND & Lithuania & Lipatova et al. 2015 \\
\hline & Ct. andorrensis catalanensis & A. sylvaticus & Spain & Cevidanes et al. 2017 \\
\hline & Ctenophthalmus nobilis & Myodes glareolus & England & Bown et al. 2004 \\
\hline & Megabothris turbidus & ND & Lithuania & Lipatova et al. 2015 \\
\hline & Megabothris walkeri & ND & Lithuania & Lipatova et al. 2015 \\
\hline & Sy. cleopatrae & ND & Israel & Rzotkiewicz et al. 2015 \\
\hline & Xenopsylla ramesis & ND & Israel & Rzotkiewicz et al. 2015 \\
\hline \multirow[t]{2}{*}{ B. henselae } & X. ramesis & ND & Israel & Rzotkiewicz et al. 2015 \\
\hline & & Meriones tristrami & Israel & Morick et al. 2010 \\
\hline B. koehlerae & Xenopsylla gerbilli & Meriones lybicus & Afghanistan & Marie et al. 2006 \\
\hline B. phoceensis & X. cheopis & R. tanezumi & Indonesia & Winoto et al. 2005 \\
\hline B. queenslandensis & X. cheopis & Rattus sp. & Thailand & Klangthong et al. 2015 \\
\hline B. quintana & X.gerbilli & Meriones lybicus & Afghanistan & Marie et al. 2006 \\
\hline B. rattaustraliani & Stephanocircus dasyure & R. fuscipes & Australia & Kaewmongkol et al. 2011 \\
\hline B. rattimassiliensis & X. cheopis & R. tanezumi & Indonesia & Winoto et al. 2005 \\
\hline B. rochalimae & X. cheopis & R. norvergicus & USA & Frye et al. 2015 \\
\hline \multirow[t]{5}{*}{ B. taylorii } & Ct. agyrtes & ND & Lithuania & Lipatova et al. 2015 \\
\hline & Ct. andorrensis catalanensis & $\begin{array}{l}\text { A. sylvaticus, } \\
\text { C. russula, M. spretus }\end{array}$ & Spain & Cevidanes et al. 2017 \\
\hline & Ct. nobilis & M. glareolus & England & Bown et al. 2004 \\
\hline & Ctenophthalmus uncinatus & ND & Lithuania & Lipatova et al. 2015 \\
\hline & Hystrichopsylla talpae & ND & Lithuania & Lipatova et al. 2015 \\
\hline
\end{tabular}




\begin{tabular}{|c|c|c|c|c|}
\hline Bacteria species & Sucking lice & Host & Country & References \\
\hline & L. taschenbergi amitina & A. sylvaticus & Spain & Cevidanes et al. 2017 \\
\hline & M. turbidus & ND & Lithuania & Lipatova et al. 2015 \\
\hline & M. walkeri & ND & Lithuania & Lipatova et al. 2015 \\
\hline & $X$. gerbilli & M. lybicus & Afghanistan & Marie et al. 2006 \\
\hline \multirow[t]{5}{*}{ B. tribocorum } & Ctenophtalmus sp. & ND & Nigeria & Kamani et al. 2013 \\
\hline & X. cheopis & R. norvergicus & USA & Reeves et al. 2007a; Frye et al. 2015 \\
\hline & & R. rattus & Algeria & Bitam et al. 2012 \\
\hline & & R. tanezumi flavipectus & China & Li et al. 2007 \\
\hline & & Rattus sp. & Thailand & Klangthong et al. 2015 \\
\hline \multirow[t]{2}{*}{ B. vinsonii } & $\begin{array}{l}\text { Polygenis bohlsi } \\
\text { bohlsi }\end{array}$ & Thrichomys fosteri & Brazil & de Sousa et al. 2018 \\
\hline & Polygenis gwyni & Sigmodon hispidus & USA & Abbot et al. 2007 \\
\hline \multirow[t]{4}{*}{ B. vinsonii arupensis } & Malareus sinomus & Peromyscus eremicus & México & Zapata-Valdés et al. 2018 \\
\hline & Orchopeas leucopus & P. eremicus & & \\
\hline & & $\begin{array}{l}\text { Peromyscus leucopus, Peromyscus } \\
\text { maniculatus }\end{array}$ & & Fernández-González et al. 2016 \\
\hline & Pleochaetis exilis & Onycomys torridus & & Zapata-Valdés et al. 2018 \\
\hline \multirow[t]{4}{*}{ B. vinsonii vinsonii } & Ctenophthalmus pseudagyrtes & Microtus sp. & USA & Reeves et al. 2007a \\
\hline & Meringis parkeri & $\begin{array}{l}\text { Onychomys arenicola, Onychomys } \\
\text { leucogaster }\end{array}$ & México & Fernández-González et al. 2016 \\
\hline & Orchopeas sexdentatus & Neotoma albigula & México & Fernández-González et al. 2016 \\
\hline & Pleochaetis exilis & $\begin{array}{l}\text { N. albigula, } O \text {. arenicola, } O . \\
\text { leucogaster, } P \text {. maniculatus }\end{array}$ & México & Fernández-González et al. 2016 \\
\hline \multirow[t]{6}{*}{ B. washoensis } & Orchopeas hirsuta & Cynomys sp. & USA & Stevenson et al. 2003; Reeves et al. 2007b \\
\hline & & Cynomys ludovicianus & México & Zapata-Valdés et al. 2018 \\
\hline & Orchopeas howardi & Sciurus carolinensis & USA & Durden et al. 2004 \\
\hline & Oropsylla montana & Otospermophilus beecheyi & USA & Osikowicz et al. 2016 \\
\hline & Pulex sp. & C. Iudovicianus & México & Fernández-González et al. 2016 \\
\hline & Thrassis fotus & Cynomys sp. & USA & Reeves et al. 2007b \\
\hline Bartonella near birtlesii & O. howardi & S. carolinensis & USA & Reeves et al. 2005b \\
\hline \multirow[t]{3}{*}{ Bartonella near clarridgeiae } & Ctenophthalmus lushuiensis & Eothenomys sp. & China & Li et al. 2007 \\
\hline & L. segnis & R. rattus & Egypt & Loftis et al. 2006 \\
\hline & P. gwyni & S. hispidus & USA & Abbot et al. 2007 \\
\hline \multirow[t]{2}{*}{ Bartonella near doshiae } & Ct. andorrensis catalanensis & A. sylvaticus & Spain & Cevidanes et al. 2017 \\
\hline & L. taschenbergi amitina & A. sylvaticus & Spain & Cevidanes et al. 2017 \\
\hline \multirow[t]{11}{*}{ Bartonella near elizabethae } & Ct. andorrensis catalanensis & A. sylvaticus & Spain & Cevidanes et al. 2017 \\
\hline & Leptopsylla algira & ND & Israel & Rzotkiewicz et al. 2015 \\
\hline & & Mus musculus & Israel & Morick et al. 2010 \\
\hline & L. taschenbergi amitina & A. sylvaticus & Spain & Cevidanes et al. 2017 \\
\hline & Ornithophaga sp. & M. spretus & Portugal & De Sousa et al. 2006 \\
\hline & Stenoponia tripectinata & M. spretus & Portugal & De Sousa et al. 2006 \\
\hline & & R. rattus & Portugal & De Sousa et al. 2006 \\
\hline & Sy. cleopatrae & ND & Israel & Rzotkiewicz et al. 2015 \\
\hline & & G.pyramidum & Israel & Morick et al. 2010 \\
\hline & X. cheopis & Rattus sp. & Thailand & Klangthong et al. 2015 \\
\hline & $X$.ramesis & ND & Israel & Rzotkiewicz et al. 2015 \\
\hline \multirow[t]{4}{*}{ Bartonella near grahamii } & Meringis altipecten & $\begin{array}{l}\text { O. arenicola, O. leucogaster, } \\
\text { Dipodomys merriami }\end{array}$ & México & Fernández-González et al. 2016 \\
\hline & Meringis arachis & $\begin{array}{l}\text { O. arenicola, O. leucogaster, } D \text {. } \\
\text { merriami }\end{array}$ & México & Fernández-González et al. 2016 \\
\hline & M. parkeri & $\begin{array}{l}\text { O. arenicola, O. leucogaster, } D \text {. } \\
\text { merriami }\end{array}$ & México & Fernández-González et al. 2016 \\
\hline & Nosopsyllus fasciatus & Rattus surifer & Thai-Myanmar Border & Parola et al. 2003 \\
\hline
\end{tabular}




\begin{tabular}{|c|c|c|c|c|}
\hline Bacteria species & Sucking lice & Host & Country & References \\
\hline & P. exilis & O. arenicola, O. leucogaster & México & Fernández-González et al. 2016 \\
\hline & Sy. cleopatrae & Meriones sacramenti & Israel & Morick et al. 2010 \\
\hline & X. ramesis & ND & Israel & Rzotkiewicz et al. 2015 \\
\hline \multirow[t]{2}{*}{ Bartonella near henselae } & Or. howardi & Glaucomys volans & USA & Reeves et al. 2007a \\
\hline & Sy. cleopatrae & Gerbillus andersoni allenbyi & Israel & Morick et al. 2010 \\
\hline Bartonella near phoceensis & X. cheopis & R. norvergicus, $R$. rattus & Egypt & Loftis et al. 2006 \\
\hline Bartonella near quintana & Or. howardi & S. carolinensis & USA & Durden et al. 2004 \\
\hline \multirow[t]{3}{*}{ Bartonella near rochalimae } & L. taschenbergi amitina & A. sylvaticus & Spain & Cevidanes et al. 2017 \\
\hline & X. cheopis & R. norvegicus & Algeria & Bitam et al. 2012 \\
\hline & X. ramesis & ND & Israel & Rzotkiewicz et al. 2015 \\
\hline Bartonella near taylorii & Ct. lushuiensis & Eothenomys sp. & China & Li et al. 2007 \\
\hline Bartonella near tribocorum & X. cheopis & R. rattus & Benin & Leulmi et al. 2014 \\
\hline $\begin{array}{l}\text { Bartonella near vinsonii } \\
\text { arupensis }\end{array}$ & Sy. cleopatrae & ND & Israel & Rzotkiewicz et al. 2015 \\
\hline \multirow[t]{9}{*}{ Bartonella sp. } & Echinophaga gallinacea & Dipodomys spectabilis & México & Fernández-González et al. 2016 \\
\hline & Ct. andorrensis catalanensis & C. russula & Spain & Cevidanes et al. 2017 \\
\hline & M. arachis & D. spectabilis & México & Fernández-González et al. 2016 \\
\hline & M. altecpin & D. spectabilis, O. arenicola & México & Fernández-González et al. 2016 \\
\hline & Or. hirsuta & Cynomys sp. & USA & Reeves et al. 2007b \\
\hline & Sy. cleopatrae & ND & Israel & Rzotkiewicz et al. 2015 \\
\hline & Thrassis aridis & D. spectabilis & México & Fernández-González et al. 2016 \\
\hline & X. cheopis & R. norvegicus & Algeria & Bitam et al. 2012 \\
\hline & & R. rattus & Algeria, Israel & Morick et al. 2010; Bitam et al. 2012 \\
\hline R. conorii & Stivalius aporus & Mus caroli & Taiwan & Kuo et al. 2016 \\
\hline \multirow[t]{15}{*}{ R. felis } & Acropsylla episema & Apodemus agrarius & Taiwan & Kuo et al. 2016 \\
\hline & Anomiopsyllus nudata & N. albigula & USA & Stevenson et al. 2005 \\
\hline & Ctenocephalides felis & Peromyscus yucatanicus & México & Peniche Lara et al. 2015 \\
\hline & & R. norvegicus & Cyprus & Psaroulaki et al. 2006 \\
\hline & & R. rattus & Cyprus & Psaroulaki et al. 2006 \\
\hline & Ct. agyrtes & Apodemus flavicollis & Lithuania & Radzijevskaja et al. 2018 \\
\hline & Ctenophthalmus calceatus calceatus & Lophuromys aquilus & Tanzania & Leulmi et al. 2014 \\
\hline & Ctenophtalmus sp. & R. norvegicus & Portugal & De Sousa et al. 2006 \\
\hline & H. talpae & Micromys minutus & Lithuania & Radzijevskaja et al. 2018 \\
\hline & L. segnis & Mus sp. & Algeria & Bitam et al. 2009 \\
\hline & Polygenis odiosus & Ototylomys phyllotis & México & Peniche Lara et al. 2015 \\
\hline & S. aporus & M. caroli & Taiwan & Kuo et al. 2016 \\
\hline & X. cheopis & R. norvegicus & Cyprus & Christou et al. 2010 \\
\hline & & R. rattus & Cyprus, Madagascar & Christou et al. 2010; Rakotonanahary et al. 2017 \\
\hline & & Rattus sp. & Afghanistan, Algeria & Marie et al. 2006; Bitam et al. 2009 \\
\hline \multirow[t]{4}{*}{ R. helvetica } & Ct. agyrtes & A. flavicollis & Lithuania & Radzijevskaja et al. 2018 \\
\hline & M. turbidus & A. flavicollis & & \\
\hline & & M. minutus & & \\
\hline & M. walkeri & A. flavicollis & & \\
\hline R. japonica & S. aporus & M. caroli & Taiwan & Kuo et al. 2016 \\
\hline R. monacensis & Ct. agyrtes & A. flavicollis & Lithuania & Radzijevskaja et al. 2018 \\
\hline R. raoultii & ND & A. flavicollis, Myodes glareolus & Germany & Obiegala et al. 2016 \\
\hline \multirow[t]{5}{*}{ R. typhi } & Ctenophthalmus congeneroides & A. agrarius & South Korea & Kim et al. 2010 \\
\hline & L. segnis & R. norvegicus & Cyprus & Christou et al. 2010 \\
\hline & & R. rattus & Cyprus, Egypt, Portugal & $\begin{array}{l}\text { De Sousa et al. 2006, Loftis et al. 2006; Christou } \\
\text { et al. } 2010\end{array}$ \\
\hline & Rhadinopsylla insolita & A. agrarius & South Korea & Kim et al.2010 \\
\hline & Xenopsylla brasiliensis & Mastomys natalensis & Tanzania & Leulmi et al. 2014 \\
\hline
\end{tabular}




\begin{tabular}{|c|c|c|c|c|}
\hline Bacteria species & Sucking lice & Host & Country & References \\
\hline & & R. rattus & Tanzania & Leulmi et al. 2014 \\
\hline & & Rattus sp. & $\begin{array}{l}\text { Democratic Republic of } \\
\text { the Congo }\end{array}$ & Leulmi et al. 2014 \\
\hline & X. cheopis & R. norvegicus & Cyprus, Egypt & Loftis et al. 2006; Christou et al. 2010 \\
\hline & & R. rattus & $\begin{array}{l}\text { Benin, Cyprus, Egypt, } \\
\text { Madagascar }\end{array}$ & $\begin{array}{l}\text { Loftis et al. 2006; Christou et al. 2010; Leulmi et } \\
\text { al. 2014, Rakotonanahary et al. } 2017\end{array}$ \\
\hline & & Rattus sp. & Argelia & Bitam et al. 2009 \\
\hline Rickettsia prowazekii & Or. howardii & G. volans & USA & Sonenshine et al. 1978 \\
\hline \multirow{3}{*}{$\begin{array}{l}\text { Candidatus Rickettsia } \\
\text { Asemboensis }\end{array}$} & E. gallinacea & R. rattus & Egypt & Loftis et al. 2006 \\
\hline & S. cleopatrae & ND & Israel & Rzotkiewicz et al. 2015 \\
\hline & $X$. ramesis & $\begin{array}{l}\text { Gerbillus dasyurus, Meriones } \\
\text { tristrami, M. musculus }\end{array}$ & Israel & Rzotkiewicz et al. 2015 \\
\hline Rickettsia felis-like & X. ramesis & ND & Israel & Rzotkiewicz et al. 2015 \\
\hline Rickettsia near monacensis & Oropsylla hirsuta & Cynomys sp. & USA & Reeves et al. 2007b \\
\hline Rickettsia sp. Oh16 & Or. howardi & S. carolinensis & USA & Reeves et al. 2005 \\
\hline Rickettsia sp. TwKM01 & S. aporus & A. agrarius & Taiwan & Kuo et al. 2016 \\
\hline $\begin{array}{l}\text { Rickettsia endosymbiont of } \\
\text { Eucoryphus brunneri }\end{array}$ & Ct. agyrtes & A. flavicollis & Lithuania & Radzijevskaja et al. 2018 \\
\hline B. henselae & Neohaematopinus sciuri & S. carolinensis & USA & Durden et al. 2004 \\
\hline \multirow[t]{4}{*}{ B. phoceensis } & Hoplopleura pacifica & R. norvegicus & Egypt & Reeves et al. 2006 \\
\hline & Polyplax spinulosa & R. norvegicus & Taiwan & Tsai et al. 2010 \\
\hline & Polyplax sp. & R. rattus & Madagascar & Brook et al. 2017 \\
\hline & & Rattus sp. & Thailand & Klangthong et al. 2015 \\
\hline \multirow[t]{4}{*}{ B. rattimassiliensis } & Hoplopleura pacifica & R. norvegicus & Egypt & Reeves et al. 2006 \\
\hline & Polyplax spinulosa & R. norvegicus & Egypt, Taiwan & Reeves et. al. 2006; Tsai et al. 2010 \\
\hline & Polyplax sp. & R. rattus & Madagascar & Brook et al. 2017 \\
\hline & & Rattus sp. & Thailand & Klangthong et al. 2015 \\
\hline B. tribocorum & Polyplax spinulosa & R. norvegicus & Taiwan & Tsai et al. 2010 \\
\hline B. vinsonii & Hoplopleura hirsuta & S. hispidus & México & Sánchez-Montes et al. 2016b \\
\hline B. washoensis & Neohaematopinus sciuri & S. carolinensis & USA & Durden et al. 2004 \\
\hline Bartonella near tribocorum & Polyplax spinulosa & R. norvegicus & Egypt & Reeves et al. 2006 \\
\hline Bartonella near washoensis & Hoplopleura sciuricola & S. carolinensis & USA & Durden et al. 2004 \\
\hline Bartonella sp. & Polyplax sp. & Thrichomys apereoides & Brazil & Fontalvo et al. 2017 \\
\hline \multirow[t]{2}{*}{ R.prowazekii } & Neohaematopinus sciuropteri & G. volans & USA & Sonenshine et al. 1978 \\
\hline & Polyplax spinulosa* & R. norvegicus & México & Mooser et al. 1931 \\
\hline \multirow[t]{2}{*}{ R. typhi } & Enderleinellus marmotae & Marmota monax & USA & Reeves et al. 2005 \\
\hline & Hoplopleura pacifica & R. norvegicus & Egypt & Reeves et al. 2006 \\
\hline
\end{tabular}

In México, nine taxa of fleas (Ctenocephalides felis, Maleareus sinomus, Meringis parkeri, Orchopeas hirsuta, O. leucopus, O. sexdentatus, Pleochaetis exilis, Pulex sp., and Polygenis odiosus) and two species of sucking lice (Hoplopleura hirsuta and Polyplax spinulosa) tested positive for at least one of four validated species of Bartonella (B. vinsonii and $B$. washoensis) and Rickettsia (R. felis and R. prowazekii). Additionally new lineages of Bartonella have been registered in six more flea species (Echinophaga gallinacea, Meringis altipecten, M. arachis, M. parkeri, Pleochaetis exilis, Thrassis aridis, Table 1). These records came from isolated studies carried out in wildlife from the southeast and northern parts, lacking data regarding central México where there is a report of human cases of murine typhus (Centro Nacional de Vigilancia Epidemiológica y Control de Enfermedades
2018; Sánchez-Montes et al. 2019). Additionally, for México, 172 species of fleas and 44 species of sucking lice, have been recorded, then, the inventory of species of both bacteria genera is still far from complete (Sánchez-Montes et al. 2013; Acosta-Gutiérrez 2014).

Due to the great diversity of potential vectors and the historical presence of human cases of murine typhus in the centre of the country; the purpose of this study was to identify the presence and diversity of Bartonella and Rickettsia species in a focus of murine typhus in Hidalgo, México.

\section{Material and Methods}

During August to September 2014, we sampled in two private ranches from Mineral del Monte and Tulancingo de Bravo (Figure 1), in the state of Hidalgo, México, close 


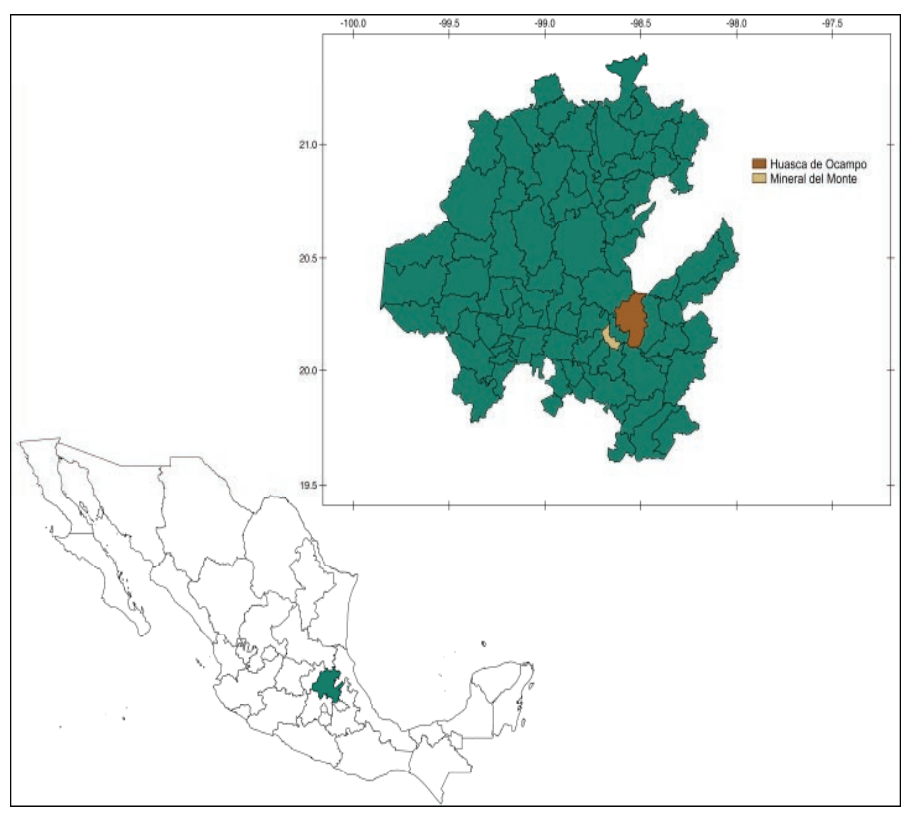

Figure 1. Sampling sites along the state of Hidalgo, México. Green: State of Hidalgo; Brown: Huasca de Ocampo; Yellow: Mineral del Monte.

to sites where human murine typhus cases have been reported (CENAPRECE 2016). This study was approved by the Ethics and Research Committee of the Medical Faculty of the Universidad Nacional Autónoma de México [FMED/ $\mathrm{Cl} / \mathrm{JMO} / 004 / 2012]$.

In order to identify the presence of several flea-borne and louse-borne pathogens (Rickettsia and Bartonella) in small mammals and their associated ectoparasites, we trapped small mammals using Sherman traps following Romero-Almaraz et al. (2007), under permission FAUT-0170 from the Secretaría del Medio Ambiente y Recursos Naturales. All mammals were sacrificed in accordance with the Guidelines of the American Society of Mammalogists for the Use of Wild Mammals in Research (Sikes et al. 2016). We performed the necropsy of each animal, extracting a portion of liver and ear which were fixed in $96 \%$ ethanol until its processing in the laboratory. Additionally, fleas and lice were recovered from host's bodies by manual inspection and fixed in absolute ethanol. Hosts and fleas were identified and deposited at the Mammal Collection and the Flea Collection of the Museo de Zoología "Alfonso L. Herrera" Facultad de Ciencias (MZFC) and Colección del Centro de Medicina Tropical, Facultad de Medicina (CMTFM), both belonging to Universidad Nacional Autónoma de México.

For morphological determination, fleas and lice were mounted on slides using the modified techniques of Kim et al. (1986) and Wirth and Marston (1968). Species were identified using specialized taxonomic keys such as Kim et al. (1986) for lice and Acosta and Morrone (2003), Hastriter (2004), Hopkins and Rothschild (1971), Morrone et al. (2000), and Traub (1950) for fleas.

From collected ectoparasites and hosts tissues, we extracted DNA with the QIAamp ${ }^{\circledR}$ DNA Mini Kit (QIAGEN, Hilden, Germany). As an endogenous internal control and for molecular identification of the ectoparasites, we amplified a
Table 2. Oligonucleotide primers used in this study.

\begin{tabular}{|c|c|c|c|c|}
\hline Gen & Primers & Sequence $\left(5^{\prime}-3^{\prime}\right)$ & $\begin{array}{c}\text { Length } \\
\text { (bp) }\end{array}$ & Reference \\
\hline & & Fleas and lice & & \\
\hline \multirow{3}{*}{$\begin{array}{l}\mathrm{COI} \text { (Cytochrome } \\
\text { oxidase subunit I) }\end{array}$} & L6625 & CCGGATCCTTYTGRTTYTTYYGGNCAYCC & \multirow[t]{2}{*}{400} & \multirow{2}{*}{$\begin{array}{l}\text { Hafner et al. } \\
1994\end{array}$} \\
\hline & H7005 & CCGGATCCACNACRTARTANGTRTCRTG & & \\
\hline & & \multicolumn{3}{|l|}{ Rickettsia sp. } \\
\hline \multirow{2}{*}{$\begin{array}{l}\text { gltA (Citrate } \\
\text { synthase) }\end{array}$} & RpCS.415 & GCTATTATGCTTGCGGCTGT & \multirow[t]{2}{*}{806} & \multirow{2}{*}{$\begin{array}{l}\text { de Souza et } \\
\text { al. (2006) }\end{array}$} \\
\hline & RpCS.1220 & TGCATTTCTTTCCATTGTGC & & \\
\hline \multirow{3}{*}{$\begin{array}{l}\text { ompB (Outer } \\
\text { membrane } \\
\text { protein B) }\end{array}$} & 120-M59 & CCGCAGGGTTGGTAACTGC & \multirow[t]{2}{*}{862} & \multirow{2}{*}{$\begin{array}{l}\text { Roux and } \\
\text { Raoult, } 2000\end{array}$} \\
\hline & $120-807$ & CCTTTTAGATTACCGCCTAA & & \\
\hline & & Bartonella sp. & & \\
\hline \multirow{2}{*}{$\begin{array}{l}\text { gltA (Citrate } \\
\text { synthase) }\end{array}$} & BhCS781.p & GGGGACCAGCTCATGGTGG & \multirow[t]{2}{*}{379} & \multirow{2}{*}{$\begin{array}{l}\text { Norman et al } \\
1995\end{array}$} \\
\hline & BhCS1137.n & AATGCAAAAAGAACAGTAAACA & & \\
\hline
\end{tabular}

fragment of $400 \mathrm{bp}$ of Cytochrome Oxidase Subunit I (COI) gene. For pathogens detection, we amplified a fragment of $g / t A$ and $o m p B$ genes specific for each group using primers and temperature conditions previously reported (Table 2 ).

The reaction mixture consisted of $12.5 \mu \mathrm{L}$ of $\mathrm{GoTaq}^{\circledR}$ Green Master Mix, 2X of Promega Corporation (Madison, WI, USA), the pair of primers (100 ng each), $6.5 \mu \mathrm{L}$ nucleasefree water and $30 \mathrm{ng}$ DNA in a final volume of $25 \mu \mathrm{L}$ (Sánchez-Montes et al. 2016a, b).

PCR products were resolved in $2 \%$ agarose gels using TAE buffer at $85 \mathrm{~V}$ during 45 minutes and visualized using an ODYSSEY CLx Imaging System (LICOR Biosciences). Purified amplification products were submitted for sequencing at Macrogen Inc., Korea.

Sequences were analysed and edited using Bioedit version 5.0.9 Sequencing Alignment Editor Copyright (c) program and deposited in GenBank under accession numbers (MG952757 to MG952772). In order to identify the species of Bartonella and Rickettsia, we used the similarity criteria of the gltA and ompB genes proposed by La Scola (2003), Fournier and Roult (2009) and Fournier et al. (2003). Global alignments were done using Clustal W (Thompson et al. 1994) and the best substitution model was selected based on the lowest BIC (Bayesian Information Criterion) score for each gene using MEGA 6.0 (Tamura et al. 2011; Sánchez-Montes et al. 2016c). Additionally phylogenetic reconstruction was done using Maximum Likelihood also in MEGA 6.0 and branch support was evaluated over 10,000 bootstrap replications.

\section{Results}

We collected 40 rodents from four species (Mus musculus, Peromyscus beatae, Rattus norvergicus, and Reithrodontomys sumichrasti), and one shrew (Sorex ventralis), which are deposited in the MZFC under the following catalogue numbers LRR001 to LRR040. We detected the presence of Bartonella DNA in four samples of liver of two P. beatae (2/26 $=7.69 \%)$ and two $R$. norvergicus $(2 / 4=50 \%)$. Sequences recovered from $P$. beatae exhibited a similarity of $98 \%$ with B. vinsonii vinsonii (a member of the Bartonella vinsonii complex) and those from R. norvergicus corresponded in a 100 $\%$, respectively with $B$. elizabethae (Figure 2 ). In the case of 


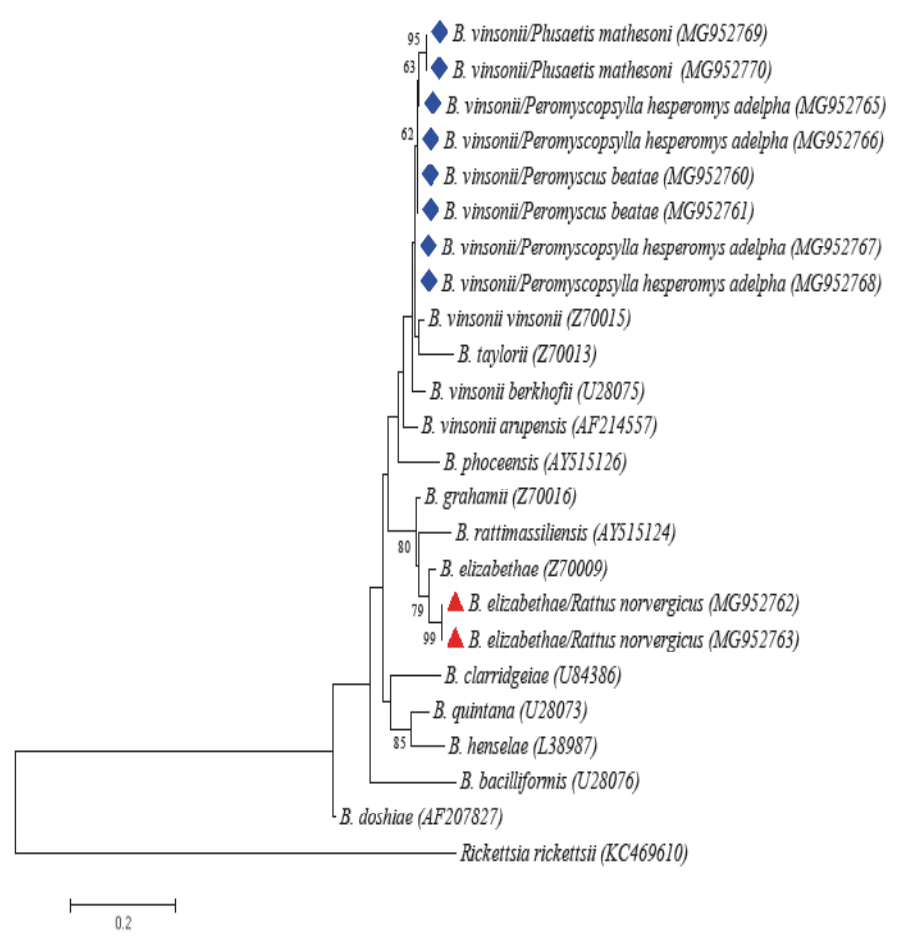

Figure 2. Maximum likelihood (ML) phylogenetic tree generated with gltA gene (300 bp) from several members of the genus Bartonella. The nucleotide substitution model was the Tamura three parameter model (T92) with discrete Gamma distribution $(+\mathrm{G})$. Bootstrap values higher than 50 are indicated at the nodes. Sequences recovered in the study are marked with blue rhombuses and red triangles.

Rickettsia detection, a single specimen of $R$. norvergicus ( $1 / 4$ $=25 \%$ ) tested positive in samples from liver and ear; we recovered sequences of $g$ lt $A$ and $o m p B$ genes which exhibited a similarity of $99 \%$ and $100 \%$ with R. typhi (Accesion

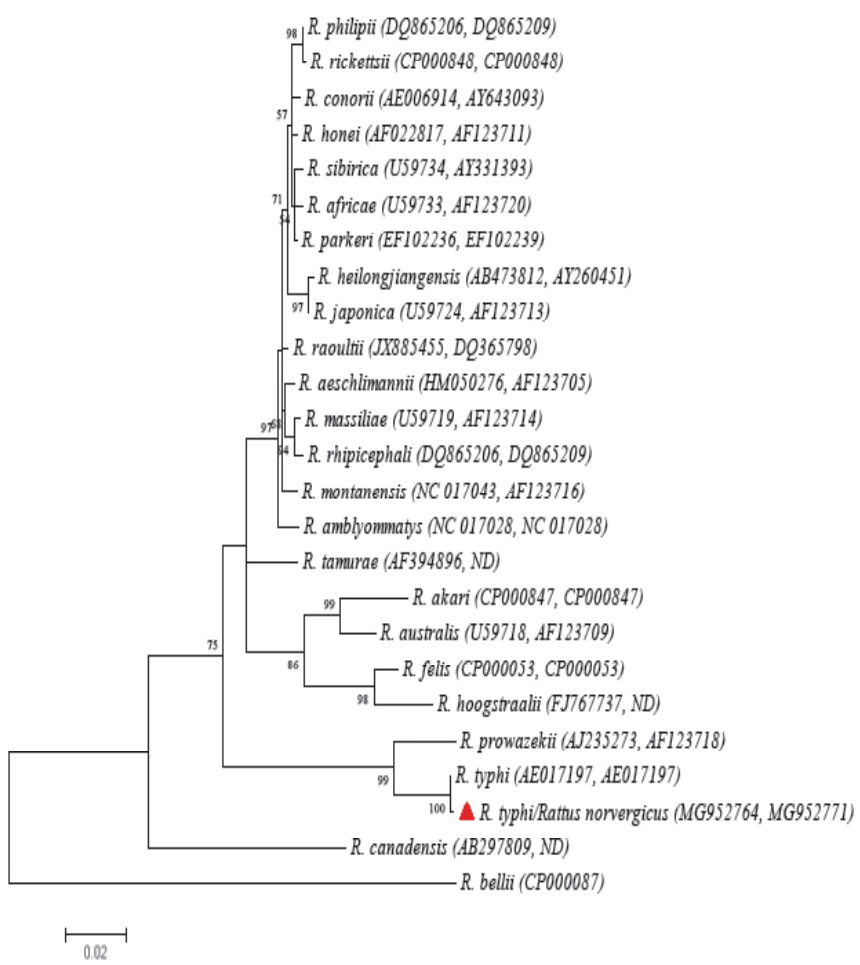

Figure 3. Maximum likelihood $(\mathrm{ML})$ phylogenetic tree generated with gltA and omp $B$ genes concatenated (1547 bp) from several members of the genus Rickettsia. The nucleotide substitution model was the Tamura three parameter model (T92) with discrete Gamma distribution (+G). Bootstrap values higher than 50 are indicated at the nodes. Sequences recovered in the study are marked with red triangles. number AE017197) deposited in GenBank (Figure 3). A single $R$. norvergicus specimen presents co-infection between B. elizabethae and R. typhi.

Hosts were infested by 47 fleas ( 18 females, 29 males), and 172 sucking lice (60 females, 39 males, 73 nymphs), distributed in six taxa, five species belonging to five families and six genera (Table 3). No fleas or lice were recovered from M. musculus and S. ventralis. After morphological identification was done, we amplified a fragment of $400 \mathrm{bp}$ of Cytochrome oxidase subunit I (COI) in all ectoparasites recovered, in order to corroborate the identification of all samples, especially of those damaged specimens and nymphal stages. DNA sequences of the COI for four of the six species analysed were deposited in GenBank with the following accession numbers: C. tecpin (MG952757), P. hesperomys adelpha (MG952758); P. mathesoni (MG952759), P. spinulosa (MG952772) and H. reithrodontomydis (KT151126). No complete sequences were obtained for J. b. breviloba. We detected the presence of the same Bartonella lineage previously refereed in $P$. beatae, in two flea species (six $P$. hesperomys adelpha and 17 P. mathesoni) recovered from the two hosts which tested positive and from three others that were negative (Table 3). Sequences from fleas and hosts shape a single cluster within our phylogenetic analysis (Fig. 1). None of the flea or sucking lice species analysed was positive for Rickettsia DNA.

\section{Discussion}

We report for the first time the presence of two species of Bartonella and one of Rickettsia in the state of Hidalgo, México. The first Bartonella species is a member of the $B$. vinsonii complex, closely related with previous sequences detected in Cricetid rodents and fleas of the northern México (Rubio et al. 2014; Fernández-González et al. 2016). Also, this is the first study to report the presence of a Bartonella in the fleas $P$. hesperomys adelpha and $P$. mathesoni and in the host $P$. beatae (Table 1). Our phylogenetic analysis grouped sequences of $B$. vinsonii from $P$. hesperomys adelpha, P. mathesoni and $P$. beatae in a single cluster, then, our inference is that both flea species could be the potential vectors of these. Additionally, positive $P$. hesperomys adelpha were recovered from negative hosts, suggesting that these fleas may disseminate the pathogen in non-infected individuals among the rodent population bacteria (Kosoy et al. 1997; Morick et al. 2010). However, it is necessary to carry out tests to verify their vectorial capacity. Both species of fleas have a restricted distribution in México, which extend along the northeastern and central parts of the country, parasitizing several cricetid species such as Peromyscus levipes, $P$. maniculatus, Reithrodontomys megalotis ( $P$. mathesoni) and $P$. difficilis ( $P$. hesperomys adelpha), so it is not unexpected that this strain of bacteria is widely distributed in the country (Ponce-Ulloa and Llorente-Bousquets 1993; Hoffman et al. 1989; Whitaker and MoralesMalacara 2005; Acosta and Fernández 2015). 
Table 3. Ecological parameters of Bartonella and Rickettsia species detected in fleas, sucking lice and small mammals in Hidalgo, México.

\begin{tabular}{|c|c|c|c|c|c|c|c|c|c|c|c|c|c|c|c|}
\hline \multicolumn{6}{|c|}{ Host } & \multicolumn{10}{|c|}{ Ectoparasite } \\
\hline Family & Species & $\mathrm{n}$ & $\mathrm{HI}$ & $\%$ & BAD & Family & Species & HP & EA & $\%$ & A & II & EI & $\%$ & BAD \\
\hline \multicolumn{16}{|c|}{ Ranch 1 Tulancingo de Bravo } \\
\hline \multirow[t]{5}{*}{ Cricetidae } & Peromyscus beatae & 20 & 2 & 10 & Bartonella vinsonii & Ceratophyllidae & Jellisonia breviloba breviloba & 2 & 3 & 10 & 0 & 2 & 0 & 0 & ND \\
\hline & & & & & & & Plusaetis mathesoni & 10 & 27 & 5 & 1 & 3 & 17 & 57 & Bartonella vinsonii \\
\hline & & & & & & Ctenophtalmidae & Ctenophtalmus tecpin & 2 & 3 & 10 & 0 & 2 & 0 & 0 & ND \\
\hline & & & & & & Leptopsyllidae & $\begin{array}{l}\text { Peromyscopsylla hesperomys } \\
\text { adelpha }\end{array}$ & 4 & 7 & 20 & 0 & 2 & 6 & 86 & Bartonella vinsonii \\
\hline & Reithrodontomys sumichrasti & 2 & 0 & 0 & ND & Hoplopleuridae & Hoplopleura reithrodontomydis & 1 & 4 & 50 & 2 & 4 & 0 & 0 & ND \\
\hline Soricidae & Sorex ventralis & 1 & 0 & 0 & ND & NR & NR & 0 & NR & $(-)$ & $(-)$ & $(-)$ & NR & NR & ND \\
\hline \multicolumn{16}{|c|}{ Ranch 2 Mineral del Monte } \\
\hline Cricetidae & Peromyscus beatae & 6 & 0 & 0 & ND & Ceratophyllidae & Plusaetis mathesoni & 1 & 3 & 17 & 1 & 3 & 0 & 0 & ND \\
\hline \multirow[t]{3}{*}{ Muridae } & Mus musculus & 8 & 0 & 0 & ND & NR & NR & 0 & NR & $(-)$ & $(-)$ & $(-)$ & NR & NR & ND \\
\hline & Rattus norvergicus & 4 & 2 & 50 & $\begin{array}{l}\text { Bartonella } \\
\text { elizabethae }\end{array}$ & Polyplacidae & Polyplax spinulosa & 4 & 172 & 100 & 43 & 43 & 0 & 0 & ND \\
\hline & & & 1 & 25 & Rickettsia typhi & & & & & & & & & & \\
\hline
\end{tabular}

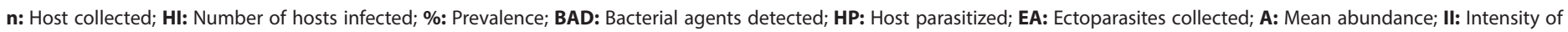
infestation; El: Ectoparasites infected; NR: Not recovered; ND: Not detected.

We also report for the first time the presence of B. elizabethae in México, a zoonotic bacterial that may causes endocarditis and neuroretinitis in humans. This agent was reported for the USA in the 1990's, however, is has become an emerging problem in several countries of Southeast Asia, Portugal and France (Regier et al. 2016; Tay et al. 2016). Bartonella elizabethae is mainly transmitted by the rat flea Xenosylla cheopis (Table 1); however, in our study we did not recovered any fleas from the four $R$. norvergicus analysed. The higher prevalence of $B$. elizabethae in collected murid rodents suggests the presence of this flea or other competent vector in the area (Bitam et al. 2012). Additionally, we compiled evidence for the first time of the presence of $R$. typhi in rodents of the state of Hidalgo. This Rickettsia produces febrile cases with a wide range of severity that can lead to systemic failure in less than $5 \%$ percent of cases (ZavalaCastro et al. 2009). In the state of Hidalgo, three cases of murine typhus had been reported between 2005 to 2010, nevertheless, in 2015 there was an outbreak with 12 cases (Centro Nacional de Vigilancia Epidemiológica y Control de Enfermedades 2018).

Only one rat reported coinfection by $B$. elizabethae and R. typhi, a phenomenon that has been previously reported, probably because both pathogens are transmitted by the same flea species (Table 1). This reinforces the hypothesis of the presence of this vector in the study area (Marie et al. 2006; Bitam et al. 2012; Frye et al. 2015). The presence of positive Norway rats for these two zoonotic pathogens is a risk to human health, because this rodent species invade suburban and urban areas, live and thrive in human settlements and could carry fleas that can feed on human hosts and produce urban outbreaks. Our findings represent the first record of several confirmed zoonotic pathogens that can cause murine typhus and endocarditis in México, which highlight the importance of the establishment of active entomological surveillance in wildlife.

\section{Acknowledgements}

We thank to A. Villalpando, O. Escorza and G. Cruz for their help in the logistics and direction of sampling. Additionally to Y. N. Lozano Sardaneta for editing our images. We are indebted to J. C. Sánchez-Montes of the Department for Teaching and Research Branch of the General Directory for Preventive Medicine in Secretaria de Comunicaciones y Transportes, who kindly reviewed our manuscript and provided a number of valuable comments. This work was supported by grants CONACyT 221405 and PAPIIT IN211418. There are no financial or commercial conflicts of interest. Daniel Sokani Sánchez Montes was supported by a fellowship from CONACyT and was a Ph.D. student of Programa de Doctorado en Ciencias Biomédicas, Universidad Nacional Autónoma de México, UNAM.

\section{Literature cited}

Aвbot, P., A. E. Aviles, L. Eller, and L. A. Durden. 2007. Mixed infections, cryptic diversity, and vector-borne pathogens: evidence from Polygenis fleas and Bartonella species. Applied and Environmental Microbiology 73:6045-6052.

Acosta, R., AND J. J. Morrone. 2003. Clave ilustrada para la identificación de los taxones supraespecíficos de Siphonaptera de México. Acta Zoológica Mexicana 89:39-53. AcostA, R. 2014. Biodiversidad de Siphonaptera en México. Revista Mexicana de Biodiversidad 85:S345-S352.

Acosta, R., And J. A. Fernández. 2015. Flea diversity and prevalence on arid-adapted rodents in the Oriental Basin, México. Revista Mexicana de Biodiversidad 86:981-988.

Bitam, I., B. Baziz, T. Kernif, Z. Harrat, P. Parola, and D. Raoult. 2009. Molecular detection of Rickettsia typhi and Rickettsia felis in fleas from Algeria. Clinical Microbiology and Infection 15:255-256.

Bitam, I., K. Dittmar, P. Parola, M. F. Whiting, and D. Raoult. 2010. Fleas and flea-borne diseases. International Journal of Infectious Diseases 8:667-676. 
Bitam, I., J. M. Rolain, V. Nicolas, Y. L. Tsai, P. Parola, V. A. K. B. GundI, AND D. RAOULT. 2012. A multi-gene analysis of diversity of Bartonella detected in fleas from Algeria. Comparative Immunology. Microbiology and Infectious Diseases 35:71-76.

BREITSCHWERDT, E. B., AND D. L. KoRDICK. 2000. Bartonella infection in animals: carriership, reservoir potential, pathogenicity, and zoonotic potential for human infection. Clinical Microbiology Reviews 13:428-438.

Bown, K. J., M. Bennet, And M. Begon. 2004. Flea-borne Bartonella grahamii and Bartonella taylorii in bank voles. Emerging Infectious Diseases 10:684-687.

Brook, C. E., Y. Bal, O. Yu, C. R. Hafaliana, S. Haewon, P. D. Andrew, C. Metcalf, Y. K. Michael, and D. Katharina. 2017. Elucidating transmission dynamics and host-parasite-vector relationships for rodent-borne Bartonella spp. in Madagascar. Epidemics 257: 56-66.

Centro Nacional de Vigilancia Epidemiológica y Control de Enfermedades (CENAPRECE). 2018. Anuarios de Morbilidad durante el periodo 1995-2015, http://www.epidemiologia.salud.gob. $\mathrm{mx} /$ anuario/html/anuarios.html (accessed 02.03.16.).

Cevidanes, A., L. Altet, A. D. Chirife, T. Proboste, and J. Millán. 2017. Drivers of Bartonella infection in micromammals and their fleas in a Mediterranean peri-urban area. Veterinary Microbiology 203:181-188.

Christou, C., A. Psaroulaki, M. Antoniou, P. Toumazos, I. loannou, A. MAZERIS, AND Y. TselentIS. 2010. Rickettsia typhi and Rickettsia felis in Xenopsylla cheopis and Leptopsylla segnis Parasitizing Rats in Cyprus. The American Journal of Tropical Medicine and Hygiene 83:1301-1304.

De Sousa, R., P. Fournier, M. Silva, F. Amaro, F. Bacellar, and D. Raoult. 2006. Molecular detection of Rickettsia felis, Rickettsia typhi and two genotypes closely related to Bartonella elizabethae. The American Journal of Tropical Medicine and Hygiene 75:727-731.

De Sousa, K. C. M., R. B. Amaral, H. M. Herrera, F. M. Santos, G. C. Macedo, P. C. E. Andrade, D. M. Barros, R. Z. Machado, and M. R. André. 2018. Genetic Diversity of Bartonella spp. in Wild Mammals and Ectoparasites in Brazilian Pantanal. Microbiology Ecological 76:544-554.

Durden, L. A., B. A. Ellis, C. W. Banks, J. D. Crowe, and J. H. Oliver. 2004. Ectoparasites of gray squirrels in two different habitats and screening of selected ectoparasites for Bartonellae. Journal of Parasitology 90:485-489.

EISEN, R. J., AND K. L. Gage. 2012. Transmission of flea-borne zoonotic agents. Annual Review of Entomology 57:61-82.

Fernández, A. M., M. Y. Kosoy, A. V. Rubio, C. B. Graham, J. A. Montenieri, L. M. Osikowicz, Y. Bal, R. Acosta, R. Ávila, K. L. Gage, and G. SuzÁn. 2016. Molecular Survey of Bartonella Species and Yersinia pestis in Rodent Fleas (Siphonaptera) From Chihuahua, México. Journal of Medical Entomology 53:199-205.

Fontalvo, M.C., A. R. Favacho, A. C. Araujo, N. M. Santos, G. M. Oliveira, D. M. Aguiar, E. R. Lemos, And M. C. Horta. 2017. Bartonella species pathogenic for humans infect pets, free-ranging wild mammals and their ectoparasites in the Caatinga biome, Northeastern Brazil: a serological and molecular study. The Brazilian Journal of Infectious Diseases S1413-8670, 30316-6.

Fournier, P. E., and D. Raoult. 2009. Current knowledge on phylogeny and taxonomy of Rickettsia spp. Annals of the New York Academy of Sciences 1166:1-11.
Fournier, P. E., J. S. Dumler, G. Greub, J. Zhang, Y. Wu, and D. Raoult. 2003. Gene sequence-based criteria for identification of new rickettsia isolates and description of Rickettsia heilongjiangensis sp nov. Journal of Clinical Microbiology 41:5456-5465.

Frye, M. J., C. Firth, M. Bhat, M. A. Firth, X. Che, D. Lee, And W. I. Lipkin. 2015. Preliminary Survey of Ectoparasites and Associated Pathogens from Norway Rats in New York City. Journal of Medical Entomology 52:253-259.

Gannon, W. L., and Animal Care and Use Committee of the American Society of Mammalogists. 2016. Guidelines of the American Society of Mammalogists for the use of wild mammals in research and education. Journal of Mammalogy 97:663-688.

Gillespie, J. J., N. C. Ammerman, M. Beier, B. S. Sobral, and A. F. Azad. 2009. Louse- and flea-borne rickettsioses: biological and genomic analyses. Veterinary Research 40:1-12.

Hastriter, M. W. 2004. Revision of the flea genus Jellisonia Traub, 1944 (Siphonaptera: Ceratohpyllidae). Annals of the Carnegie Museum 73:213-238.

Hoffmann, A., M. OJeda, ANd G. López. 1989. Los ectosimbiontes de Peromyscus difficilis (J. A. Allen, 1891) (Rodentia:Cricetidae). Revista de la Sociedad Mexicana de Historia Natural 40:49-58. Hopkins, G. H. E., AND M. Rothschild. 1971. An illustred catalogue of the Rothschild Collection of fleas (Siphonaptera) in the British Museum (Nat. Hist.) 5.

Kaewmongkol, G., S. Kaewmongkol, H. Burmej, M. D. Bennett, P. A. Fleming, P. J. Adams, A. F. Wayne, U. Ryan, P. J. IRWin, and S. G. Fenwick. 2011. Diversity of Bartonella species detected in arthropod vectors from animals in Australia. Comparative Immunology Microbiology Infection Disease 34:411-7.

Kamani, J., D. Morick, K. Y. Mumcuoglu, and S. Harrus. 2013. Prevalence and diversity of Bartonella species in commensal rodents and ectoparasites from Nigeria, West Africa. PLoS Negl Tropical Disease 7:e2246.

Kim, K. C., H. D. Pratt, and C. J. Stojanovich. 1986. The sucking lice of North America: an illustrated manual for identification. Philadelphia/London: The Pennsylvania State University Press, University Park. Philadelphia, U. S. A.

Kim, H. C., Y. C. YAnG, S. T. Chong, S. J. Ko, S. E. LeE, T. A. Klein, AND J. S. ChAe. 2010. Detection of Rickettsia typhi and seasonal prevalence of fleas collected from small mammals in the Republic of Korea. Journal Wildlife Diseases 46:165-172.

Klangthong, K., S. Promsthaporn, S. Leepitakrat, A. L. Schuster, P. W. McCardle, M. Kosoy and R. Takhampunya. 2015. The Distribution and Diversity of Bartonella Species in Rodents and Their Ectoparasites across Thailand. PLoS One 10:e0140856.

Kosoy, M. Y., R. L. Regnery, T. Tzianabos, E. L. Marston, D. C. Jones, D. Green, G. O. Maupin, J. G. Olson, and J. E. Childs. 1997. Distribution, diversity, and host specificity of Bartonella in rodents from the Southeastern United States. The American Journal of Tropical Medicine and Hygiene 57:578-88.

KosOY, M, D. T. HAYMAN, AND K. S. CHAN. 2012. Bartonella bacteria in nature: where does population variability end and a species start. Infection Genetics and Evolution 12:894-904.

Kuo, C. C., J. L. Huang, T. E. Lin, And H. C. Wang. 2016. Detection of Rickettsia Spp. And Host and Habitat Associations of Fleas (Siphonaptera) in Eastern Taiwan. Medical and Veterinary Entomology 26:341-350. 
La Scola, B., Z. Zeaiter, A. Khamis, and D. Raoult. 2003. Genesequence-based criteria for species definition in bacteriology: The Bartonella paradigm. Trends Microbiology 11:318-321.

Leulmi, H., C. Socolovschi, A. Laudisolt, G. Houemenou, B. Davoust, I. BitAm, AND P. Parola. 2014. Detection of Rickettsia felis, Rickettsia typhi, Bartonella species and Yersinia pestis in fleas (Siphonaptera) from Africa. PLoS Neglected Tropical Diseases 8:e3152.

LI, D. M., Q. Y. LIU, D. Z. Yu, J. Z. Zhang, Z. D. Gong And X. P Song. 2007. Phylogenetic analysis of Bartonella detected in rodent fleas in Yunnan, China. Journal of Wildlife Diseases 43:609-617.

Lipatova, I., A. Paulauskas, I. Puraite, J. Radzijevskaja, L. Balciauskas, AND V. Gedminas. 2015. Bartonella infection in small mammals and their ectoparasites in Lithuania. Microbes and Infection 17:884-888.

Loftis, A. D., W. K. Reeves, D. E. Szumlas, M. M. Abbassy, I. M. Helmy, J. R. MORIARITY, AND G. A. DASCH. 2006. Surveillance of Egyptian fleas for agents of public health significance: Anaplasma, Bartonella, Coxiella, Ehrlichia, Rickettsia, and Yersinia pestis. The American Journal of Tropical Medicine and Hygiene. 75:41-8.

Marie, J. L., P. E. Fournier, J. M. Rolain, B. Davoust, And D. Raoult. 2006. Molecular detection of Bartonella quintana, B. elizabethae, $B$. koehlerae, B. doshiae, B. taylorii, and Rickettsia felis in rodent fleas collected in Kabul, Afghanistan. The American Journal of Tropical Medicine and Hygiene 74:436-439.

Merhes,V., E. Angelakis, C. SocolovsChi, AndD. Raoult. 2014. Genotyping, evolution and epidemiological findings of Rickettsia species. Infection, Genetics and Evolution 25:122-137.

Mooser, H., M. R. CAstaneda, And H. Zinsser. 1931. The transmission of the virus of Mexican typhus from rat to rat by Polyplax spinulosa. Journal of Experimental Medicine 54:567-575.

Morick, D., B. R. Krasnov, I. S. Khokhlova, G. I. Shenbrot, M. Y. Kosoy, AND S. Harrus. 2010. Bartonella genotypes in fleas (Insecta: Siphonaptera) collected from rodents in the Negev Desert, Israel. Applied and Environmental Microbiology 76:68646869.

Morrone, J. J., R. Acosta, And A. L. Gutiérrez. 2000. Cladistics, biogeography, and host relationships of the flea subgenus Ctenophthalmus (Alloctenus), with the description of a New Mexican species (Siphonaptera: Ctenophthalmidae). Journal of the New York Entomological Society 108:1-12.

Obiegala, A., C. Oltersdorf, C. Silaghi, D. Kiefer, M. Kiefer, D. Woll, And M. Pfeffer. 2016. Rickettsia spp. in small mammals and their parasitizing ectoparasites from Saxony, Germany. Veterinary Parasitology: Regional Studies and Reports 5:19-24

Osikowicz, L. M., S. A. Billeter, M. F. Rizzo, M. P. Rood, A. N. Freeman, J. E. Burns, R. Hu, P. Juieng, V. Loparev, and M. Kosoy. 2016. Distribution and diversity of Bartonella washoensis strains in ground squirrels from California and their potential link to human cases. Vector Borne Zoonotic Diseases 16:683-690.

Parola, P., O. Y. Sanogo, K. Lerdthusnee, Z. Zeaiter, G. Chauvancy, J. P. Gonzalez, R. S. Miller, S. R. Telford, C. Wongsrichanalai, and D. RAOULT. 2003. Identification of Rickettsia spp. and Bartonella spp. in from the Thai-Myanmar border. Annals of the New York Academy of Sciences 990:173-81.

Peniche, L. G., R. K. Dzul, O. C. Pérez, and C. J. Zavala. 2015. Rickettsia typhi in rodents and $R$. felis in fleas in Yucatán as a possible causal agent of undefined febrile cases. Revista del
Instituto de Medicina Tropical de São Paulo 57:129-132.

Ponce-Ulloa, H. E., and J. Llorente-Bousquets. 1993. Distribución de los Siphonaptera (Arthropoda, Insecta) en la Sierra de Atoyac de Álvarez, Guerrero, México. México: Universidad Nacional Autónoma de México: Publicaciones especiales del Instituto de Biología, No. 11.

Psaroulaki, A., M. Antoniou, A. Papaeustathiou, P. Toumazos, P, F. LOUKAIDES, AND Y. TSELENTIS. 2006. Short Report: First Detection of Rickettsia felis in Ctenocephalides felis fleas parasitizing rats in Cyprus. The American Journal of Tropical Medicine and Hygiene 74:120-122.

Radzijevskaja, J., E. Kaminskiené, I. Lipatova, D. MardosaitéBusaitiené, L. Balčlauskas, M. Stanko, and A. Paulauskas. 2018. Prevalence and diversity of Rickettsia species in ectoparasites collected from small rodents in Lithuania. Parasites and Vectors 11:375-385.

Rakotonanahary, R. J., A. Harrison, A. N. Maina, A. L. Richards, M. RAJerison, AND S. Telfer. 2017. Molecular and serological evidence of flea-associated typhus group and spotted fever group rickettsial infections in Madagascar. Parasites and Vectors 4:125-133.

Reeves, W. K., M. P. Nelder, And J. A. KoreCKI. 2005. Bartonella and Rickettsia in fleas and lice from mammals in South Carolina, U. S. A. Journal Vector Ecology 30:310-315

Reeves, W. K., D. E. Szumlas, J. R. Moriarity, A. D. Loftis, M. M. Abbassy, I. M. Helmy, and G. A. Dasch. 2006. Louse-borne bacterial pathogens in lice (Phthiraptera) of rodents and cattle from Egypt. Journal of Parasitology 92:313-318.

Reeves, W. K., T. E. Rogers, L. A. Durden, and G. A. Dasch. 2007 a. Association of Bartonella with the fleas (Siphonaptera) of rodents and bats using molecular techniques. Journal Vector Ecology 32:118-22.

Reeves, W. K., T. E. Rogers, and G. A. Dasch. 2007b. Bartonella and Rickettsia from fleas (Siphonaptera: Ceratophyllidae) of prairie dogs (Cynomys spp.) from the western United States. Journal Parasitology 93:953-955.

Regier, Y., F. O Rourke, And V. A. Kempf. 2016. Bartonella spp. - a chance to establish One Health concepts in veterinary and human medicine. Parasite Vectors 9:261-273.

Romero-Almaraz, M. L., C. SÁnchez-Hernández, C. García-Estrada, and R. D. OWEn. 2007. Mamíferos pequeños. Manual de técnicas de captura, preparación, preservación y estudio. México, Distrito Federal. Las Prensas de Ciencias.

Rubio, A. V., R. Avila-Flores, L. M. Osikowicz, Y. Bal, G. Suzan, and M. Y. Kosor. 2014. Prevalence and genetic diversity of Bartonella strains in rodents from northwestern México. Vector Borne Zoonotic Disease 14:838-845.

Rzotkiewicz, S., R. Gutiérrez, B. R. Krasnov, D. Morick, I. S. Khokhlova, Y. Nachum-Biala, G. Baneth, and S. Harrus. 2015. Novel evidence suggests that a 'Rickettsia felis-like' organism is an endosymbiont of the desert flea, Xenopsylla ramesis. Molecular Ecology 24:1364-73.

Sánchez-Montes, S., C. Guzmán-Cornejo, L. León-Paniagua, and G. RIVAS. 2013. A checklist of sucking lice (Insecta: Phthiraptera: Anoplura) associated with Mexican wild mammals, including geographical records and a host-parasite list. Zootaxa 3722:183-203.

Sánchez-Montes, S., C. Guzmán-Cornejo, F. Ramírez-Corona, and L. León-Paniagua. 2016a. Sucking lice (Insecta: Psocodea: 
Anoplura) associated with rodents distributed in the neotropical region of México. Revista Mexicana de Biodiversidad 87:427-435.

Sánchez-Montes, S., C. Guzmán-Cornejo, L. G. Herrera-Montalvo, A. D. Richman, J. J. Flores-Martínez, G. F. García-Ruiz, M. BerzunzaCruz, P. Gaytán, R. Pérez-Montfort, and I. Becker. $2016 \mathrm{~b}$. Presence of Bartonella sp. in the sucking louse Hoplopleura hirsuta collected from hispid cotton rats (Sigmodon hispidus) in México. Southwestern Entomologist 41:1031-1036.

Sánchez-Montes, S., C. Guzmán-Cornejo, Y. Martínez-Nájera, I. Becker, J. M. Venzal, And M. B. Labruna. 2016c. Rickettsia lusitaniae associated with Ornithodoros yumatensis (Acari: Argasidae) from two caves in Yucatan, México. Ticks Tick Borne Disease 7:1097-1101.

Sánchez-Montes, S., P. Colunga-Salas, E. A. Fernández-Figueroa, M. L. Hernández-Medel, C. R. Benítez, and I. Becker. 2019. Murine typhus in México City: report of an imported case. Revista do Instituto de Medicina-Tropical de Sao Paulo. 61:e16.

Sonenshine, D. E., F. M. Bozeman, M. S. Williams, S. A. Masiello, D. P. Chadwick, N. I. Stocks, D. M. Lauer, and B. L. Elisberg. 1978. Epizootiology of epidemic typhus (Rickettsia prowazekii) in flying squirrels. American Journal of Tropical Medicine and Hygiene 27:339-49.

Stevenson, H. L., B. Ying, Y. K. Michael, J. A. Montenierl, J. L. Lowell, C., M. C. Chu, K. L. Gage. 2003. Detection of Novel Bartonella Strains and Yersinia pestis in Prairie Dogs and Their Fleas (Siphonaptera: Ceratophyllidae and Pulicidae) Using Multiplex Polymerase Chain Reaction. Journal of Medical Entomology 40: 329-337.

Tamura, K., D. Peterson, N. Peterson, G. Stecher, M. Nel, and S. KUMAR. 2011. MEGA6: molecular evolutionary genetics analysis using maximum likelihood, evolutionary distance, and maximum parsimony methods. Molecular Biology and Evolution, http://dx.doi.org/10.1093/molbev/msr121.

TaY, S. T., K. L. Kho, W. Y. WeE, and S. W. Choo. 2016. Wholegenome sequence analysis and exploration of the zoonotic potential of a rat-borne Bartonella elizabethae. Acta Tropical 155:25-33.

Thompson, J. D., D. Higgins, AND T. J. GiBson. 1994. CLUSTAL W: improving the sensitivity of progressive multiple sequence alignment through sequence weighting, position-specific gap penalties and weight matrix choice. NucleicAcids Research 22:4673-4680.

Traub, R. 1950. Siphonaptera of Central America and México: A morphological study of the adeagus with descriptions of new genera and species. Fieldiana Zoology l:1-127.

Tsal, Y. L., S. T. Chuang, C. C. Chang, P. H. Kass, and B. B. Chomel. 2010. Bartonella species in small mammals and their ectoparasites in Taiwan. American Journal of Tropical Medicine and Hygiene 83:917-923.

Tsal, Y. L., C. C. Chang, S. T. Chuang, and B. B. Chomel. 2011. Bartonella species and their ectoparasites: selective host adaptation or strain selection between the vector and the mammalian host? Comparative Immunology, Microbiology and Infectious Diseases 34:299-314.

Whitaker, J. O., AND J. B. Morales-Malacara. 2005. Ectoparasites and other associates (ectodytes) of mammals of México. Pp. 535-666, in Contribuciones mastozoológicas en homenaje a Bernardo Villa (Sánchez-Cordero, V., and R. A. Medellín, eds.). Instituto de
Biología e Instituto de Ecología, Universidad Nacional Autónoma de México; Comisión Nacional para el Conocimiento y Uso de la Biodiversidad, Distrito Federal, México.

Winoto, I. L., H. Goethert, I. N. Ibrahim, I. Yuniherlina, C. Stoops, I. Susanti, W. Kania, J. D. Maguire, M. J. Bangs, S. R. Telford $3^{\text {RD }}$, AND C. Wongsrichanalai. 2005. Bartonella species in rodents and shrews in the greater Jakarta area. The Southeast Asian Journal of Tropical Medicine and Public Health 36:1523-1529.

WIRTH, W. W., AND N. MARSTON. 1968. A method for mounting small insects on microscope slides in Canada balsam. Annals of Entomology Society of America 61:783-784.

Zapata-Valdés, C., R. Avila-Flores, K. Gage, J. Holmes, J. Montenierri, M. Kosoy AND G. SuzÁN. 2018. Mammalian hosts, vectors, and bacterial pathogens in communities with and without blacktailed prairie dogs (Cynomys ludovicianus) in Northwestern México. Journal of Wildlife Diseases 54:26-33.

Zavala-Castro, J. E., J. E Zavala-Velázquez, and J. E. S. Uicab. 2009. Murine typhus in child, Yucatan, México. Emerging Infectious Diseases 15:972-974.

Associated editor: Jesús Fernández Submitted: November 27, 2018; Reviewed: March 18, 2019; Accepted:April 24, 2019; Published on line: April 30, 2019. 
80 THERYA Vol. 10 (2): 69-79 